慶應義塾大学学術情報リポジトリ

Keio Associated Repository of Academic resouces

\begin{tabular}{|c|l|}
\hline Title & Variability of androsterone metabolism in male wistar rats \\
\hline Sub Title & \\
\hline Author & $\begin{array}{l}\text { 松井, 道夫(Matsui, Michio) } \\
\text { 青柳, 忍( Aoyagi, Shinobu) }\end{array}$ \\
\hline Publisher & 共立薬科大学 \\
\hline Publication year & 1979 \\
\hline Jtitle & $\begin{array}{l}\text { 共立薬科大学研究年報 (The annual report of the Kyoritsu College of } \\
\text { Pharmacy). No.24 (1979. ) ,p.81-82 }\end{array}$ \\
\hline JaLC DOI & \\
\hline Abstract & \\
\hline Notes & 抄録 \\
\hline Genre & Technical Report \\
\hline URL & https://koara.lib.keio.ac.jp/xoonips/modules/xoonips/detail.php?koara_id=AN00062898-0000002 \\
\hline
\end{tabular}

慶應義塾大学学術情報リポジトリ(KOARA)に掲載されているコンテンツの著作権は、それぞれの著作者、学会または出版社/発行者に帰属し、その権利は著作権法によって 保護されています。引用にあたっては、著作権法を遵守してご利用ください。

The copyrights of content available on the KeiO Associated Repository of Academic resources (KOARA) belong to the respective authors, academic societies, or publishers/issuers, and these rights are protected by the Japanese Copyright Act. When quoting the content, please follow the Japanese copyright act. 
No. 24 (1979)

\title{
Variability of Androsterone Metabolism in Male Wistar Rats*
}

\author{
Michio Matsui and Shinobu Aoyagi \\ 松井道夫, 青柳 忍
}

\begin{abstract}
Some remarkable features characterize the metabolism of androsterone in female Wistar rats, i.e. discontinuous variations in biliary metabolites and hepatic UDP-glucuronyltransferase activity. These observations together with recent findings on the metabolism of androsterone glucuronide and androsterone sulfate indicate that the hepatic UDPglucuronyltransferase must be principally responsible for the diversity of the in vivo metabolism of androsterone in female rats. Experiments with male Wistar rat liver demonstrated the existence of variations in transferase activity toward androsterone similar to those of female rats. These results indicate clearly the variability of androsterone metabolism in male rats. In the present paper, $\left[{ }^{3} \mathrm{H}\right]$ androsterone and $\left[{ }^{3} \mathrm{H}\right]$ androsterone glucuronide were administered intraperitoneally into male Wistar rats, and the biliary metabolites were isolated and identified by gas chromatography-mass spectrometry.

The results of the present study demonstrate that androsterone was metabolized extensively to oxygenated steroids in male Wistar rats. Furthermore, wide individual differences were observed in biotransformation and biliary excretion. It was found that half of the rats (HE rats) excreted large amounts of steroid monoglucuronides rapidly into bile, whereas the remaining rats (LE rats) excreted various steroid conjugates slowly into bile. In marked contrast, the injected androsterone glucuronide was excreted rapidly into bile and behaved like a metabolic end-product, as was found in female Wistar rats and humans. There has been accumulating evidence that steroid glucuronides are excreted in rat bile more rapidly than steroid sulfates.
\end{abstract}

In a previous paper, we described the marked variations in biliary metabolites of androsterone in female Wistar rats. About half of the rats excreted mainly androsterone glucuronide into bile, while the remaining rats excreted predominantly the monosulfates of $\mathrm{C}_{19} \mathrm{O}_{2}$ and $\mathrm{C}_{19} \mathrm{O}_{3}$ steroids in the bile. Subsequent in vitro studies with male and female Wistar rats revealed the discontinuous variations in hepatic microsomal UDP-glucuronyltransferase activities toward androsterone but not toward testosterone, females showing greater enzyme activity than males. The rat with a high level of the transferase activity (HG) and the rat with a low level of the transferase activity (LG) were found approximately in the ratio $5: 4$ and the $H G$ to $L G$ specific activity ratio was about 9 , irrespective of the sex. Thus, the variability of the UDP-glucuronyltransferase activity should be principally responsible for the large variations in the in vivo metabolism of androsterone in female rats. On the other hand, androsterone was metabolized mainly to polyoxygenated steroid

* 㶱報告は Biochem. Pharmacol., 28, 1023 (1979) に発表。 
monoglucuronides in male $\mathrm{HE}$ rats. Gas chromatography-mass spectromety analysis of the trimethylsilyl derivatives of androsterone metabolites revealed the occurrence of several monooxo-trihydroxy and tetrahydroxy steroids. Since we identified 2- and 16oxygenated $\mathrm{C}_{19} \mathrm{O}_{3}$ steroids as androsterone metabolites, we synthesized three $2,3,16,17$ tetraoxygenated steroids by introduction of a 16 -hydroxy group into $2 \alpha, 3 \alpha$-dihydroxy- $5 \alpha$ androstan-17-one. In the HE rats, androsterone was metabolized to the monoglucuronides of androsterone, $2 \alpha, 3 \alpha$-dihydroxy- $5 \alpha$-androstan-17-one, $3 \beta, 17 \beta$-dihydroxy- $5 \alpha$-androstan- 16 one, $5 \alpha$-androstane- $3 \alpha, 16 \alpha, 17 \beta$-triol, $2 \alpha, 3 \alpha, 16 \alpha$-trihydroxy- $5 \alpha$-androstan- 17 -one, $2 \alpha, 3 \alpha, 17 \beta$ trihydroxy- $5 \alpha$-androstan-16-one, and $5 \alpha$-androstane- $2 \alpha, 3 \alpha, 16 \alpha, 17 \beta$-tetrol. In the LE rats, . $5 \alpha$-androstane- $3 \alpha, 16 \alpha, 17 \beta$-triol and $3 \beta, 17 \beta$-dihydroxy- $5 \alpha$-androstan-16-one were isolated as the monosulfate and the disulfate respectively. In addition, $5 \alpha$-androstane- $3 \beta, 16 \alpha, 17 \beta$ triol was identified in the mono- and disulfate fractions. Low recovery of androsterone in the monoglucuronide fraction might reflect the increased hydroxylase activities in male rats, leading to a type of metabolite different from that in female rats. However, these results imply that the variation of UDP-glucuronyltransferase should exist not only for androsterone but for the oxygenated metabolites of androsterone.

The relationship between the UDP-glucuronyltransferase activity in vitro and the glucuronidation in vivo is not clear. The glucuronidation in vivo can be affected by several factors such as UDP-glucuronic acid, $\beta$-glucuronidase, and other metabolizing enzymes besides UDP-glucuronyltransferase. The situation is complicated by the fact that UDPglucuronyltransferase is latent and probably inside the microsomal vesicle. The enzyme can be activated by physical, chemical, or enzymatic perturbation of the membrane structure. Comparative studies indicate that UDP-glucuronyltransferase may be operating largely in a constrained form in vivo. From comparative studies on the glucuronidation of 1-naphthol in perfused liver and hepatic UDP-glucuronyltransferase, Bock et al. reported that the markedly decreased UDP-glucuronyltransferase in Gunn rats does not lead to impaired glucuronide formation in perfused livers, due probably to compensatory activation of the latent enzyme. In contrast to this, our female Wistar rats showed good correlation between glucuronidations in vivo and in vitro. This may be ascribable to the striking differences in UDP-glucuronyltransferase activities toward androsterone of $\mathrm{HE}$ and $L E$ rats. In fact, activation of the latent enzyme with Triton X-100 amplified the diversity between HG and LG microsomes. To extend our findings, it is of interest to investigate the specificity of "androsterone UDP-glucuronyltransferase" in male rats. Work is now under progress in our laboratory to study the nature and extent of the variability of hepatic UDP-glucuronyltransferase in rats of the Wistar and other strains. 